\title{
Funding Terrorism: The Problem of Ransom Payments
}

\author{
YVONNE M. DUTTON*
}

\section{TABLE OF CONTENTS}

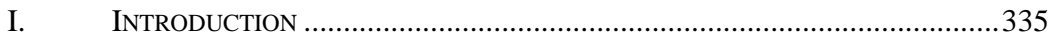

II. THE RISE OF KIDNAPPING FOR RANSOM TO FUND TERRORISM......................340

III. The No-Concessions Policy and the RECENT MEASURES

CALLING FOR A UNIVERSAL TERRORIST RANSOM BAN ...............................345

A. The No-Concessions Policy and its Underlying Rationale ...............345

B. The Recent Calls for a Universal Terrorist Ransom Ban................348

C. Legally-Binding or Not: A Textual Analysis ...................................350

IV. MAKING THE CASE FOR THE RECENT MEASURES: NoRm InfluENCE ..........355

A. $\quad$ Norm Influence and the Terrorist Ransom Ban Measures ..............355

B. Considering the Alternative: Force Instead of Persuasion ................358

1. Obstacles to a Legally-Binding Terrorist Ransom

Ban Directed at Governments.................................................359

2. Obstacles to a Legally-Binding Terrorist Ransom Ban

Directed at Individuals ..........................................................361

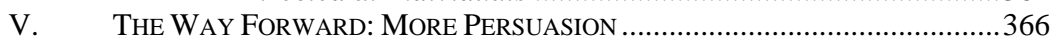

\section{INTRODUCTION}

In January 2009, kidnappers captured four Westerners who were part of a tour group traveling on holiday in West Africa. ${ }^{1}$ The tourists were returning to Niger after attending a cultural festival in Mali when kidnappers

* (C) 2016 Yvonne Dutton. Associate Professor, Indiana University Robert H. McKinney School of Law. Please do not cite or share without permission.

1. Financial Action Task Force, Organised Maritime Piracy and Related KIDNAPPING FOR RANSOM 27 (2011) [hereinafter 2011 FATF Report]. 
began shooting at their vehicles. ${ }^{2}$ One vehicle managed to escape, but the one containing a German woman, a Swiss couple, and a British man was disabled by the gunfire. The kidnappers moved the four Westerners to a neighboring country. ${ }^{3}$ Although some reports indicate that a nomadic rebel group carried out the initial capture, ultimately the terrorist group al Qaeda in the Land of the Islamic Maghreb (AQIM) took charge of ransom negotiations. ${ }^{4}$ AQIM initially offered to exchange the British hostage, Edwin Dyer, for a high-level terrorist group member imprisoned in Britain. ${ }^{5}$ When the British government rejected that offer, AQIM followed with a demand for approximately ten million euros to release Mr. Dyer and one of the Swiss hostages. ${ }^{6}$ That demand too went unmet, and AQIM executed Mr. Dyer. ${ }^{7}$ The German and Swiss hostages did not suffer the same fate as Mr. Dyer: they were eventually released, reportedly in exchange for ransom payments totaling about eight million euros. ${ }^{8}$

This tragic story is but one of many that illustrates how a country's ransom policy can affect the likelihood that its citizens will survive a kidnapping for ransom by a terrorist organization. Britain, like the United States, has a no-concessions policy and will not pay to have citizens released. ${ }^{9}$ Both countries defend their policies, arguing that paying ransoms merely fuels and funds further attacks, thereby putting more

2. Rukmini Callimachi, Paying Ransoms, Europe Bankrolls Qaeda Terror, N.Y. Times (July 29, 2014), http://www.nytimes.com/2014/07/30/world/africa/ransomingcitizens-europe-becomes-al-qaedas-patron.html?_r=0.

3. Id.; 2011 FATF Report, supra note 1.

4. Id.

5. See Xan Rice \& Robert Booth, Al-Qaida Group Demands Release of Abu Qatada or British Hostage Will be Killed, GUARDIAN (Apr. 26, 2009, 7:01 PM), http:// www.theguardian.com/world/2009/apr/27/alqaida-north-africa-hostages [https://perma.cc/ 9NKQDADZ].

6. Matthew Weaver, British Hostage Edwin Dyer 'Killed by Al-Qaida,' GUARDIAN (June 3, 2009, 5:11 AM), http://www.theguardian.com/uk/2009/jun/03/edwindyer-hostage-killed-al-qaida [https://perma.cc/MN44-NGWP].

7. Id. (quoting a statement from AQIM indicating that Mr. Dyer was killed "so that he, and with him the British state, may taste a tiny portion of what innocent Muslims taste every day at the hands of the crusader and Jewish coalition to the east and to the west.”).

8. Callimachi, supra note 2.

9. See Lizzie Deardon, Steven Sotloff Beheaded: David Cameron Under Pressure to Negotiate with ISIS After Threat to Kill British Hostage, INDEPENDENT (Sept. 3, 2014), http://www.independent.co.uk/news/world/middle-east/steven-sotloff-beheaded-davidcameron-under-pressure-to-negotiate-with-isis-after-threat-to-kill-british-hostage-970 7786.html [https://perma.cc/F2M2-A9D6] (stating that the British "no concessions" policy dates from the 1970s); Press Statement, Richard Boucher, U.S. Dep't of State, Int'l Terrorism: American Hostages (Feb. 20, 2002), http://2001-2009.state.gov/r/pa/prs/ps/2002/8190. htm [https://perma.cc/G7Y8-X7AL] [hereinafter Boucher Statement] (referencing the U.S. policy). 
innocent individuals at risk of being taken hostage in the future. ${ }^{10}$ Nor do these countries back down when confronted with the reality that their citizens have been murdered at the hands of terrorists. In the aftermath of AQIM's execution of Mr. Dyer, Britain's Prime Minister Gordon Brown said, "This tragedy reinforces our commitment to confront terrorism . . . and strengthens our determination never to concede to the demands of terrorists, nor to pay ransoms." "11 The United States stands by its policy even after the Islamic State in Iraq and Syria (ISIS) executed two American journalists in late 2014, and states that its policy is not coldhearted, but instead is designed to protect U.S. citizens by depriving terrorist organizations of the funds they need to carry out future terrorist acts. ${ }^{12}$

Although other countries deny paying ransoms, the evidence suggests otherwise. Reports indicate that between 2008 and 2014, European countries paid more than $\$ 100$ million in ransom payments to al Qaeda and its affiliates. $^{13}$ The payments are made in secret, but the benefits obtained are readily apparent: the citizens of these countries return home, rather than suffer gruesome deaths at the hands of terrorists. ${ }^{14}$ Commentators, however, charge that those who pay are causing greater long-term damage in that

10. See, e.g., Prime Minister's Office, The Threat Posed by Kidnapping for

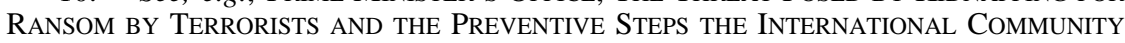
CAN TAKE (2013), https://www.gov.uk/government/publications/g8-summit-kidnappingfor-ransom-by-terrorists-extract-of-communique/the-threat-posed-by-kidnapping-forransom-by-terrorists-and-the-preventive-steps-the-international-community-can-take [https://perma.cc/V3FD-6RRC] (stating ransom payments constitute a source of income that supports the recruitment efforts of terrorist groups and strengthens their capacity to carry out future attacks, all of which increases the risk to British nationals); Press Release, U.S. Dep't of the Treasury, Remarks of Under Secretary for Terrorism and Financial Intelligence David Cohen before the Center for a New American Security on 'Confronting New Threats in Terrorist Financing’ (Mar. 4, 2014), https://www.treasury.gov/press-center/ press-releases/Pages/j12308.aspx [https://perma.cc/Y6X5-UJTG] [hereinafter Cohen Statement] ("Refusing to pay ransoms or to accede to other terrorist demands is the surest way to convince potential hostage-takers that they will not be rewarded for their crime.”).

11. Weaver, supra note 6.

12. See Rob Garver, U.S. Says a No-Ransom Policy Could Weaken ISIS, FISCAL TIMES (Oct. 23, 2014), http://www.thefiscaltimes.com/2014/10/23/US-Says-No-RansomPolicy-Could-Weaken-ISIS [https://perma.cc/93XB-DUYB] (quoting David Cohen, Under Secretary for Terrorism and Financial Intelligence).

13. Callimachi, supra note 2.

14. See, e.g., id. (reporting on the release of the Swiss and German hostages held along with Mr. Dyer); Charles Bremner, France Pays Ransom to al-Qaeda for Last Hostage, TIMES (Dec. 10, 2014, 12:01 AM), http://www.thetimes.co.uk/tto/news/world/europe/ article4292595.ece [https://perma.cc/Z9GK-LZJW] (reporting that France paid for the release of a 16th citizen being held hostage by an al Qaeda affiliate). 
they are helping terrorist organizations stay in business because of their regular-albeit secret-ransom payments. ${ }^{15}$ Apart from state sponsorship, kidnapping for ransom has become the largest source of terrorist funding. ${ }^{16}$

Recently, concerns about the increased role ransoms play in funding terrorism have led to calls for a universal policy banning ransom payments to terrorists. In June 2013, the Group of Eight (G8) leaders issued a communiqué in which they recognized that ransom payments to terrorists help strengthen the organization and fund future incidents of kidnapping for ransom. ${ }^{17}$ The G8 leaders accordingly "welcome[d] efforts to prevent kidnapping and to secure the safe release of hostages without ransom payments." 18 In January 2014, the United Nations Security Council unanimously adopted a resolution expressing concern about the increase in terrorist kidnappings for ransom and the fact that the ransom payments fund future hostage-takings. ${ }^{19}$ It further called on states to prevent terrorists from benefiting from ransom payments and to work with the private sector so that it would respond to kidnappings without paying ransoms. ${ }^{20}$ Additional Security Council resolutions referencing a ransom ban have followed. ${ }^{21}$

What, though, is the import of these recent measures? Analysis of the text of the communiqué and the resolutions shows that they do not create clear, binding, and enforceable obligations on states to refuse to pay ransoms to terrorists. This means that there is also reason to expect that states that have previously acceded to terrorist ransom demands or permitted their citizens to pay ransoms to terrorists may not change their behavior. Thus, these recent measures present a puzzle: namely, if they are not obligatory and backed by enforcement mechanisms to hold states accountable, why were they adopted?

15. Callimachi, supra note 2 (stating that "Europe has become an inadvertent underwriter of Al Qaeda” through its ransom payments); see also David Blair, France Boosted Al-Qaeda in Mali by Paying $£ 11$ million in Ransoms, Says US Ambassador, TELEGRAPH (Feb. 8, 2013, 2:36 PM), http://www.telegraph.co.uk/news/worldnews/africa andindianocean/mali/9857723/France-boosted-al-Qaeda-in-Mali-by-paying-11m-in-ransomssays-US-ambassador.html (quoting a former US Ambassador to Mali as saying that various European governments paid ransoms to AQIM for the release of their citizens and that the monies were used to help the terrorist organization buy weapons, grow stronger, and recruit members).

16. Cohen Statement, supra note 10.

17. G8 Lough Erne Leader Communiqué, June 18, 2013, ๆ 75, http://www.g8.utoronto. ca/summit/2013lougherne/lough-erne-communique.html [https://perma.cc/T7UE-642K] [hereinafter G8 Communiqué].

18. Id. at 97.

19. S.C. Res. 2133, ๆ 6 (Jan. 27, 2014).

20. S.C. Res. 2133, qा 3, 10 (Jan. 27, 2014).

21. S.C. Res. 2170, ๆ 17 (Aug. 15, 2014); S.C. Res. 2199, ๆ ๆ 19-20 (Feb. 12, 2015). 
This Article draws on the literature about norm influence ${ }^{22}$ to suggest an answer: adopting these measures has the potential to impact behavior in a meaningful and constructive way in the future. A norm refers to the appropriate or desired behavior within a community as to a particular issue. ${ }^{23}$ A new norm spreads with the help of agents, typically referred to as norm entrepreneurs, ${ }^{24}$ who use persuasion to convince a critical mass of actors in the international community to adopt the preferred behavior. ${ }^{25}$ In other words, over time, norms can become so pervasive that they change behavior. ${ }^{26}$

In fact, this Article suggests that the only realistic avenue to produce change in this context is through persuasion, as opposed to force. Consider the ethical dilemma. Even if a state is comfortable enforcing its own noconcessions policies, why would it want to assume the ethical burden of forcing another state to sacrifice the lives of its citizens? States may feel similarly as regards the private sector: while they may not want the private sector to pay ransoms, punishing individuals who pay under duress for the safe return of their loved ones is not generally consistent with the criminal law: it seems ethically and morally wrong. Urging states and citizens to refuse to pay ransoms because doing so serves the greater goals of depriving terrorists of funding and the motivation for future kidnappings is a

22. See generally Martha Finnemore \& Kathryn Sikkink, International Norm Dynamics and Political Change, 52 INT'L ORG.. 887, 895 (1998) (explaining norm influence as a three-stage process that involves, norm emergence, norm acceptance, and norm internalization).

23. Id. at 891 (“[N]orms involve standards of 'appropriate' or 'proper behavior.””); see also W. Andy Knight, The Development of the Responsibility to Protect-From Evolving Norm to Practice, 3 GLOBAL ReSP. PROTECT 3, 18 (2011) ("Norms can therefore be understood as .... standards or patterns of behavior that proscribe and prescribe the appropriateness of a given act.”).

24. Finnemore \& Sikkink, supra note 22, at 896-97 (defining norm entrepreneurs as the critical agents who call attention to and frame issues so as to usher in a new norm reflecting an alternative and more appropriate standard of conduct).

25. See, e.g., Simon Rushton, The UN Secretary-General and Norm Entrepreneurship: Boutros Boutros-Ghali and Democracy Promotion, 14 Global Governance 95, 98 (2008) (citing Finnemore \& Sikkink).

26. Finnemore and Sikkink, for example, note that “[w]omen's suffrage . . . began as a demand for domestic change in a handful of countries and eventually became an international norm.” Finnemore \& Sikkink, supra note 22, at 893 . Knight traces the development of a "responsibility to protect" norm over many years and argues that there is now some evidence that the norm is being institutionalized. Knight, supra note 23, at 32-34. 
different matter. When one urges, as opposed to forces, one does not assume the ultimate decision of whether to pay or not.

The section that follows provides some background on the rise in kidnapping for ransom to finance terrorism, including a description of how the funds are used to help some groups and further their terrorist activities. The remaining sections seek to explain the puzzle identified above: why the G8 states would issue a communiqué and why the Security Council would adopt resolutions that do not create clear and binding obligations backed by enforcement measures to hold states accountable should they fail to adhere to-and make their citizens adhere to-a terrorist ransom ban.

\section{THE RISE OF KIDNAPPING FOR RANSOM TO FUND TERRORISM}

In the last several years, kidnapping ${ }^{27}$ for ransom (KFR) has become a main source of terrorist funding, with some groups collecting tens of millions of dollars from ransoms. ${ }^{28}$ Apart from state sponsorship, as of 2014, KFR has become the "greatest source of terrorist funding and the most challenging terrorist financing threat." ${ }^{29}$ According to the Financial Action Task Force, KFR is now considered by

law enforcement agencies worldwide as a significant source of revenue for terrorist groups often operating in politically unstable countries where central authority is often weak, public and private corruption is endemic, and the social fabric of those nations has unraveled to a considerable degree. ${ }^{30}$

27. Kidnapping refers to confining a person against her will without legal authority. Kidnapping for ransom means that the perpetrators seek some financial or political consideration, such as the payment of money or the release of prisoners, before they will free the confined individual. See 2011 FATF Report, supra note 1, at 958.

28. See, e.g., Cohen Statement, supra note 10; Memorandum from the Global Counterterrorism Forum on Good Practices in Preventing and Denying the Benefits of Kidnapping for Ransom by Terrorists (Dec. 8, 2014), https://www.thegctf.org/documents/10162/ 159874/Algiers+Memorandum-English.pdf [https://perma.cc/GA7A-NENF] [hereinafter Algiers Memorandum]. The Global Counterterrorism Forum was formed in 2011 and is comprised of member states that work closely with the United Nations with the goal of implementing the U.N.'s Global Counter-Terrorism Strategy. It provides advice to address counterterrorism challenges with the help of senior policy makers and experts on counterterrorism from around the world. See About the GCTF, GLOBAL COUNTERTERRORISM FORUM, https://www.thegctf.org/web/guest/mission [https://perma.cc/X6KU-AY92] (last visited June 11, 2016).

29. Cohen Statement, supra note 10.

30. 2011 FATF Report, supra note 1, at 9 49. The Financial Action Task Force is an intergovernmental policy-making organization that issues non-binding, but influential, recommendations to "promote effective implementation of legal, regulatory and operational measures for combating money laundering, terrorist financing and other related threats to the integrity of the international financial system.” See About: Who We Are, FATF, http://www. fatf-gafi.org/pages/aboutus/ [https://perma.cc/FU3R-Q96Z] (last visited June 11, 2016). Since its creation in 1989, FATF has grown to include thirty-six member countries. See 
Experts suggest that the recent uptick in KFR as a source of terrorist funding can be linked to the international community's relative success in implementing measures that have stemmed the flow of traditional funding sources - namely, contributions from states, organizations, and individuals. ${ }^{31}$ For example, since the September 11th attacks, individual states and the international community have enforced a powerful regime of sanctions against terrorist organizations and those who fund them. ${ }^{32}$ They have also enforced regulations to increase financial transparency so that terrorist organizations can no longer easily move funds through banks or other financial institutions. ${ }^{33}$ The good news is that these methods have proved successful in eradicating some forms of terrorist financing. The bad news is that some terrorist groups have found that employing kidnapping for ransom as a funding tactic can bring in millions. ${ }^{34}$

In fact, the ransoms paid to al Qaeda and its affiliates between 2008 and 2014 total more than $\$ 125$ million. ${ }^{35}$ In 2014 alone, ISIS ${ }^{36}$ apparently took

About: Members \& Observers, FATF, http://www.fatf-gafi.org/pages/aboutus/membersand observers/ [https://perma.cc/GRP7-JVRL] (last visited June 11, 2016).

31. See Cohen Statement, supra note 10.

32. See, e.g., id.

33. Id.; see also Associated Press, Cash Strapped Al Qaeda Turns to Kidnapping and Ransoms to Pay Operational Costs, Fox News (June 19, 2011), http://www.fox news.com/world/2011/06/19/turn-to-kidnapping-showed-bin-ladens-interest/ [https://perma. cC/QJ9A-4KP9] (quoting a U.S. official as stating that information in files found in Osama bin Laden's compound is consistent with other evidence showing that al Qaeda is pursuing kidnappings for ransom as a way to reline its declining coffers).

34. Algiers Memorandum, supra note 28.

35. Callimachi, supra note 2.

36. Historically, ISIS traces back to the Iraq faction of al Qaeda—al Qaeda in Iraq (AQI). AQI was weakened in Iraq in 2007 as a result of “Awakening," fighting against the terrorist organization that was supported by the United States. With the Syrian conflict that started in 2011, AQI moved into Syria and began expanding its ranks. By 2013, the group's leader, Abu Bakr al-Baghdadi, spread the group’s influence back into Iraq and changed its name to ISIS. ISIS and its leader have had a falling out with al Qaeda's leadership, and since early 2014, the group operates independently of al Qaeda. ISIS is also known by the name ISIL, which stands for Islamic State of Iraq and the Levant. ISIS: Trail of Terror, ABC NEws, http://abcnews.go.com/WN/fullpage/isis-trail-terror-isisthreat-us-25053190 [https://perma.cc/58HT-PZWF] (last updated Feb. 23, 2015); Zachary Laub \& Jonathan Masters, Backgrounder: Islamic State of Iraq and Syria, CounCIL ON FOREIGN RELATIONS, http://www.cfr.org/iraq/islamic-state/p14811 [https://perma.cc/S8R4ALZB] (last updated May 18, 2015). The group is also known as Daesh. Felicia Schwartz, One More Name for Islamic State: Daesh, Wall Street J. (Dec. 23, 2014, 12:04 PM), http://blogs.wsj.com/washwire/2014/12/23/one-more-name-for-islamic-state-daesh/. 
in about $\$ 45$ million in ransom payments. ${ }^{37}$ AQIM $^{38}$ has also received substantial sums in exchange for its agreement to release the innocent hostages it was holding: it received about $\$ 75$ million in ransom payments between 2010 and 2014. ${ }^{39}$ In terms of the individual ransom payments to AQIM, they average over $\$ 6$ million for the release of one hostage. ${ }^{40}$ Another al Qaeda affiliate, al Qaeda in the Arabian Peninsula (AQAP), ${ }^{41}$ took in some $\$ 20$ million in ransom payments between 2011 and 2013. ${ }^{42}$

The evidence shows that these funds are used to sustain, and even grow, the organizations that collect them. Monies from ransom payments allow

terrorist groups to recruit and indoctrinate new members, acquire sophisticated weapons and communications gear such as satellite phones, establish training camps and support units, including "safe houses" and transportation operations, as well as provide financial resources which can be used to bribe government officials, law enforcement personnel and others who can be of use to a terrorist organisation in conducting its nefarious activities. ${ }^{43}$

The leader of AQAP wrote that half of the group's "battle costs" come from payments to release captured hostages. ${ }^{44}$ As to AQIM, government experts in Britain and the U.S. agree that KFR constitutes the group's

37. Associated Press, ISIS Received up to $\$ 45 M$ in Ransom in Last Year, N.Y. Post (Nov. 25, 2014, 2:46 PM), http://nypost.com/2014/11/25/isis-received-up-to-45m-inransom-in-last-year/ [https://perma.cc/85EK-FGSG] [hereinafter ISIS Received] (quoting a U.N. expert monitoring sanctions against al Qaeda).

38. AQIM is an al Qaeda affiliate that operates in the Sahara and the Sahel-a region that includes Niger, Mauritania, and Mali. It seeks to rid North Africa of Western influence and install fundamentalist regimes based on sharia in Algeria, Libya, Mali, Mauritania, Morocco, and Tunisia. The group's tactics include "guerilla-style raids ... and suicide bombings of military government, and civilian targets.” Zachary Laub \& Jonathan Masters, Backgrounder: Al-Qaeda in the Islamic Maghreb (AQIM), COUNCIL ON FOREIGN RELATIONS, http://www.cfr.org/terrorist-organizations-and-networks/al-qaedaislamic-maghreb-aqim/p12717 [https://perma.cc/8XLR-U2KL] (last updated Mar. 27, 2015).

39. ISIS Received, supra note 37.

40. 2011 FATF Report, supra note 1 , at 90.

41. Formed in 2009, AQAP is a union of the Saudi and Yemeni branches of al Qaeda. Analysts consider the group to be the most lethal franchise of al Qaeda, with close to 1,000 members - up from about 300 members in 2009. AQAP has claimed responsibility for many attacks in the region where it operates. It has also attempted to strike the United States homeland. AQAP was the terrorist group behind the failed attempt to bomb a Detroit-bound jet on Christmas day 2009. Like AQIM, AQAP's mission is to "purge Muslim countries of Western influence" and install fundamentalist Islamist regimes. Backgrounder: Al-Qaeda in the Arabian Peninsula (AQAP), COUNCIL ON FOREIGN RELATIONS, http://www.cfr. org/yemen/al-qaeda-arabian-peninsula-aqap/p9369 [https://perma.cc/3538-7M3Q] (last updated June 19, 2015).

42. Isis Received, supra note 37.

43. 2011 FATF Report, supra note 1 , at 959.

44. Callimachi, supra note 2. 
primary source of revenue for its yearly budget of approximately fifteen million euros. ${ }^{45}$

Although there is not one standard way to conduct a kidnapping for ransom, recent kidnappings by al Qaeda affiliates follow a similar pattern. First, the terrorist groups generally minimize the risks to group members by outsourcing the initial hostage-taking to criminal organizations working on a commission. ${ }^{46}$ Once the terrorist group receives the hostages, it then observes a long period of silence designed to create some panic among the hostage's loved ones. ${ }^{47}$ For instance, ISIS kept the capture of journalist James Foley secret for some sixteen months before the terrorists notified his family. ${ }^{48}$

Thereafter, negotiations for a ransom begin, often with a video showing the hostages begging their governments to pay for the hostage's safe release. ${ }^{49}$ Additional videos usually follow showing the hostages surrounded by armed guards in an effort to reinforce the group's message that the hostage will be executed if their demands are not met. Ransom negotiations, which are apparently guided by al Qaeda's central leadership in Pakistan even for kidnappings in Yemen and Mali, can drag out for months or even years. ${ }^{50}$ Payments to the terrorist groups often happen with the aid of third party intermediaries who negotiate and facilitate the transfer of ransom payments into a designated bank account or through an alternative remittance system, such as a hawala. ${ }^{51}$ As a former U.S. ambassador to Mali explains,

45. 2011 FATF Report, supra note 1, at 9 १ 76-77.

46. Callimachi, supra note 2; see also Julian Borger \& Helen Pidd, Al-Qaida Murders British Tourist Seized in Mali, GuARDIAN (June 3, 2009, 4:23 PM), http://www. theguardian.com/world/2009/jun/03/edwin-dyer-al-qaida-mali [https://perma.cc/9TEP-92TT] (stating that Tuareq rebels captured Edwin Dyer and his fellow tourists and then sold the hostages to AQIM).

47. Callimachi, supra note 2.

48. David Rohde, Did America's Policy on Ransom Contribute to James Foley's Killing?, REUTERs (Aug. 20, 2014), http://blogs.reuters.com/david-rohde/2014/08/20/didamerican-policy-help-kill-james-foley/ [https://perma.cc/68NM-NQ54].

49. Callimachi, supra note 2; see also Al Qaeda Video Shows British-American Hostage, CBS NEws (Dec. 6, 2014, 6:12 AM), http://www.cbsnews.com/news/al-qaedain-yemen-aqap-video-british-american-hostage-luke-somers/ [https://perma.cc/RPY6SJX3] (describing a video showing British-American hostage Luke Somers stating that AQAP had been holding him hostage for over one year and asking for help).

50. Callimachi, supra note 2.

51. 2011 FATF Report, supra note 1, at 9 62. Hawala is a remittance system that operates outside of traditional banking channels. It relies on a system of trust and personal relationships, with transfers of money taking place based on communications between hawala dealers, often with no accompanying negotiable instruments. PATRICK M. JOST \& 
governments use circuitous routes and pass the money indirectly through different accounts until it ends up in the terrorists' hands. ${ }^{52}$

A kidnapping can end with the release of the hostage if the hostage's government or loved ones succumb to the terrorist group's ransom demands. Governments typically deny that they pay ransoms to terrorists. Yet although the details are often shrouded in secrecy, the evidence shows that the terrorist groups holding the citizens of some countries do receive hefty ransoms in order to free the hostages. ${ }^{53}$ For example, Switzerland denied that it had paid a ransom for the release of the Swiss citizen who was held along with Mr. Dyer. According to a source close to the transaction, however, the Swiss government budget thereafter contained an additional line item for humanitarian aid to Mali. ${ }^{54}$ France denied that it paid approximately $\$ 27$ million in ransom for the release of four French citizens who had been captured by AQIM while working in Niger for the French nuclear group, Areva. Nevertheless, a relative of a remaining victim said that the government had told her that while France would not pay the terrorists, the employer could do so. ${ }^{55}$ Others allege that the ransom funds came from the coffers of France's own Secret Service. ${ }^{56}$

On the other hand, when the terrorists' ransom demands are not met, the usual outcome is a statement or a video released by the terrorists confirming the hostage's gruesome death. ${ }^{57}$ Governments with no-concessions policies,

Harjit Singh Sandhu, U.S. DeP'T of Treasury, The Hawala Alternative RemitTance SYSTEM AND ITS ROLE IN MONEY LAUNDERING 5, http://www.treasury.gov/resourcecenter/terrorist-illicit-finance/Documents/FinCEN-Hawala-rpt.pdf [https://perma.cc/G2T3WCX4].

52. See Alexandria Sage \& Sophie Louet, France Plays Down Report of Ransom Paid for Niger Hostages, REUTERS (Feb. 8, 2013, 3:27 PM), http://www.reuters.com/ article/2013/02/08/us-france-hostages-idUSBRE9170YJ20130208 [https://perma.cc/ZN4F$\mathrm{DH} 5 \mathrm{H}]$ (explaining that when France and other governments pay ransoms to AQIM, the money passes to the Malian government and then to the terrorists).

53. Callimachi, supra note 2 (referencing the European governments' denials that they pay ransoms, but confirming payments from sources who spoke on the condition of anonymity).

54. Susan Misicka, Pay or Let Die: Ransom Money Debate Heats Up, SwISs INFO (July 30, 2014, 6:37 PM), http://www.swissinfo.ch/eng/pay-or-let-die-ransom-moneydebate-heats-up/40530660 [https://perma.cc/Z5QL-AMSB].

55. Abdoulaye Massalatchi \& Nicholas Vinocur, France Denies Paying Ransom as Sahel Hostages Return, ReUTERS (Oct. 30, 2013, 9:39 AM), http://www.reuters.com/ article/2013/10/30/us-france-niger-hostages-idUSBRE99T09220131030 [https://perma.cc/ MN6V-W57C].

56. Millions Paid to Free French AQIM Hostages, Report, RFI (Oct. 30, 2013), http://www.english.rfi.fr/africa/20131030-millions-paid-free-french-aqim-hostages-report [https://perma.cc/2RKZ-ZTQP] [hereinafter Millions Paid].

57. See, e.g., Weaver, supra note 6 (referencing the terrorists' message about the execution of British citizen, Edwin Dyer); Chelsea J. Carter, Video Shows ISIS Beheading U.S. Journalist James Foley, CNN NEws (Aug. 20, 2014, 11:17 AM), http://www.cnn. 
like the United States, do launch military missions to rescue their citizens being held captive by terrorists. Most of those missions, though, do not result in the safe return of the hostage. ${ }^{58}$ The United States' attempt to rescue American journalists James Foley and Steven Sotloff from their ISIS captors in Syria did not succeed. ${ }^{59}$ In December 2014, the United States deployed dozens of Navy SEAL commandos in an effort to rescue an American photojournalist held hostage by AQAP in Yemen. Nonetheless, the terrorists killed the American, Luke Somers, and his fellow hostage from South Africa, Pierre Korkie, when they realized that the rescue effort was underway. ${ }^{60}$

\section{The No-CONCESSIONS POLICY AND THE RECENT MEASURES CALLING FOR A UNIVERSAL TERRORIST RANSOM BAN}

\section{A. The No-Concessions Policy and its Underlying Rationale}

As noted above, some countries like the United States and Britain have long adhered to a strict policy of granting no concessions to terrorists. ${ }^{61}$ The United States emphasizes that while it will use all appropriate resources to gain the safe return of any hostages, the official policy is "to deny hostage takers the benefits of ransom, prisoner releases, policy changes, or other acts of concession." 62 The United States also urges its citizens and businesses not to pay ransoms to terrorists, as does Britain. ${ }^{63}$ Indeed, according to James Foley's parents, the United States government threatened them with prosecution if they paid a ransom to ISIS for the

com/2014/08/19/world/meast/isis-james-foley/index.html [https://perma.cc/976J-A7B2] (referencing the release of a video showing the beheading of James Foley and ISIS's threat to kill another American being held captive).

58. David Martin \& Debora Patta, U.S.-led Hostage Rescues Rarely Successful, Always Dangerous, CBS NEws (Dec. 8, 2014, 7:57 PM), http://www.cbsnews.com/news/ u-s-led-hostage-rescues-rarely-successful-always-dangerous/ [https://perma.cc/S4ZT-7S2L].

59. Nicholas Schmidle, Inside the Failed Raid to Save Foley and Sotloff, NEW YORKER (Sept. 5, 2014), http://www.newyorker.com/news/news-desk/inside-failed-raidfree-foley-sotloff [https://perma.cc/P8WR-DR82].

60. Kareem Fahim \& Eric Schmitt, 2 Hostages Killed in Yemen As U.S. Rescue Effort Fails, N.Y. Times (Dec. 6, 2014), http://www.nytimes.com/2014/12/07/world/ middleeast/hostage-luke-somers-is-killed-in-yemen-during-rescue-attempt-americanofficial-says.html.

61. See supra Part I.

62. Boucher Statement, supra note 9.

63. Id.; Joe Sinclair, Government's Refusal to Negotiate Ransom Under Fire, PA NEWs (Feb. 1, 2010). 
release of their son. ${ }^{64}$ A government spokesperson, however, denied that the State Department "told the family they could be prosecuted for paying ransom," stating that the Department instead was only helping the family "understand what our laws are about terrorists or paying ransom to terrorists." 65

Countries that adhere to such no-concessions policies argue that paying ransoms encourages additional kidnappings and also funds future acts of terrorism. United States' Under Secretary for Terrorism and Financial Intelligence, David S. Cohen, has stated that "there is no doubt that the payment of ransom just fuels the appetite for additional kidnapping operations..." and refusing to pay ransoms helps "the people who are contemplating that tactic recognize that there is no pot of gold at the end of the rainbow." 66 In his remarks to the United Nations Security Council during a briefing on terrorism, Britain's Foreign Secretary urged against regarding ransom payments to hostage takers as a "necessary evil," and argued that paying millions to hostage takers will only "encourage more kidnaps and fund murder" since major attacks can be mounted for only tens of thousands of dollars. ${ }^{67}$ In September 2014, Prime Minister David Cameron explained the country's refusal to give in to ISIS's ransom demands, stating that ransom payments to the terrorist group are used to promote terrorism. ${ }^{68}$

There is no doubt that adhering to a strict policy against paying ransoms is costly-lives of innocent victims are lost in the short term. Recent events well illustrate this fact. ISIS executed American journalist James

64. Brian Ross et al., 'So Little Compassion’: James Foley’s Parents Say Officials Threatened Family Over Ransom, ABC NeWs (Sept. 12, 2014, 5:58 PM), http://abcnews. go.com/International/government-threatened-foley-family-ransom-payments-mother-slain/ story?id=25453963 [https://perma.cc/JT7Q-883R].

65. Id.

66. Interview by Chatham House with David S. Cohen, U.S. Under Sec'y for Terrorism \& Fin. Intelligence, in London, U.K. (Oct. 5, 2012), http://www.chatham house.org/sites/default/files/public/Meetings/Meeting\%20Transcripts/051012CohenQA.pdf [https://perma.cc/T6SP-FVWT] [hereinafter Cohen Q \& A]; see also UN Urges End to Ransom Payments, AlJAZEERA (Jan. 28, 2014), http://www.aljazeera.com/news/americas/ 2014/01/un-urges-end-ransom-payments-20141281206630778.html [https://perma.cc/Z9L22U23] (quoting U.S. Ambassador to the U.N., Samantha Powers, as saying "[e]very ransom paid to a terrorist organization encourages future kidnapping operations”).

67. William Hague, Foreign Sec'y, Foreign \& Commonwealth Office, Address to the Security Council Briefing on Terrorism (Sept. 27, 2010), https://www.gov.uk/government/ speeches/foreign-secretary-supports-un-efforts-against-terrorism-condemns-ransompayments-to-terrorists [https://perma.cc/V7MD-7AHC].

68. David Cameron Says UK Won't Pay Ransoms to Terrorists as Tayside Man Held by ISIS, EVENING TELEGRAPH (Sept. 4, 2014, 8:40 AM), http://www.eveningtelegraph. co.uk/news/uk-world/david-cameron-says-uk-won-t-pay-ransoms-to-terrorists-as-taysideman-held-by-isis-1.558228 [https://perma.cc/PJ6S-7SSP]. 
Foley after the United States refused to release prisoners or pay the requested ransom payment in the amount of around $\$ 130$ million. ${ }^{69}$ By contrast, French and Spanish journalists held hostage by ISIS were released, allegedly because the governments of the hostages paid sizable ransoms for their return. ${ }^{70}$

Accordingly, in the short term, a policy that permits acceding to a ransom demand produces a benefit in that the lives of particular hostages are saved. Yet, according to countries with no-concessions policies, the long-term benefits of abiding by their policy outweigh the short-term benefits of paying. In November 2014, the United States again argued that granting concessions puts "all American citizens overseas at greater risk for kidnapping" and also "sustain[s] the very same terrorist organizations that we are working to destroy." "71 For those individuals or businesses who may want to pay a ransom for the release of a loved one, there is another long-term cost associated with the decision of some governments to pay hefty ransoms - the price of a ransom becomes so inflated that some will not be able to pay it. ${ }^{72}$

69. See Rukimi Callimachi, For James Foley's Family, U.S. Policy Offered No Hope, N.Y. TIMES (Sept. 15, 2014), http://www.nytimes.com/2014/09/16/us/for-hostagesfamily-us-policy-offered-no-hope.html?_r=0 (describing ISIS's demand for a \$130 million ransom and the release of certain prisoners in exchange for Mr. Foley's safe release).

70. France Denies Paying Ransom for Reporters Abducted in Syria, DAILY STAR (Apr. 28, 2014, 12:12 AM), http://www.dailystar.com.lb/News/Middle-East/2014/Apr28/254608-france-denies-paying-ransom-for-reporters-abducted-in-syria.ashx [https://perma.cc/ RZ7E-FFBM] [hereinafter France Denies] (noting France's denial that its Defense Minister delivered \$18 million in a suitcase to Ankara in exchange for the release of the four French journalists); Timothy McGrath, These Are the Countries That Have (Probably) Paid Ransom to the Islamic State, GLOBAL PoST (Jan. 28, 2015, 8:00 AM), http://www.globalpost.com/ dispatch/news/war/150121/these-are-the-countries-have-probably-paid-ransom-the-islamicstate [https://perma.cc/WP6T-H893] (noting Spain's denial that it paid a ransom for the release of several Spanish journalists who were being held by ISIS); Conal Urquhart, Kidnapped French Journalists Released 10 Months After Abduction in Syria, GuARDIAN (Apr. 19, 2014), http://www.theguardian.com/world/2014/apr/19/kidnapped-french-journalistssafe-turkey-syria-border [https://perma.cc/LB7X-ANWK] (describing the release of four French journalists and a Spanish journalist who were being held by ISIS).

71. Rick Gladstone, U.S. Agencies Review Policy on Hostages, N.Y. TimEs (Nov. 18, 2014), http://www.nytimes.com/2014/11/19/world/middleeast/isis-hostages-us-reviewspolicies.html.

72. Julian Borger, Kim Willsher, \& Steven Burgen, Terrorist Ransoms: Should Governments Pay Up or Stick to Their Principles?, GUARDIAN (Aug. 22, 2014, 3:26 PM), http://www.theguardian.com/media/2014/aug/22/terrorist-ransom-government-pay-jamesfoley [https://perma.cc/Z5P6-WN8F] (citing individuals who have been engaged in 


\section{B. The Recent Calls for a Universal Terrorist Ransom Ban}

As the terrorists' coffers have grown, so too have the calls to stand united in refusing to give in to their ransom demands. U.K. Prime Minister David Cameron led the movement in June 2013, when he announced at the G8 Summit ${ }^{73}$ that he would seek a pledge from member countries agreeing to ban ransoms. ${ }^{74}$ The resulting pledge is memorialized in a G8 communiqué that reads:

We are committed to protecting the lives or our nationals and reducing terrorist groups' access to the funding that allows them to survive and thrive in accordance with relevant international conventions. We unequivocally reject the payment of ransoms to terrorists in line with UN Security Council Resolution 1904 (2009) which requires that Member States prevent the payment of ransoms, directly or indirectly, to terrorists designated under the UN Al Qaeda sanctions regime through the freezing of funds and other assets. We welcome efforts to prevent kidnapping and secure the safe release of hostages without ransom payments, such as those recommended by the [Global Counterterrorism Forum], specifically in the Algiers Memorandum on Good Practices on Preventing and Denying the Benefits of Kidnapping for Ransom by Terrorists. ${ }^{75}$

The referenced Algiers Memorandum issued by the Global Counterterrorism Forum recommends a set of "non-binding good practices for all states to consider implementing to prevent hostage-taking, keep the hostage safe, and deny terrorists the financial and other benefits from such actions."76 Among those good practices is denying terrorists "the benefits of ransom - while seeking to secure the safe release of the hostage(s) - through financial, diplomatic, intelligence, law enforcement and other means and resources, as appropriate, not excluding the use of force . . .."77

hostage negotiations with terrorist groups for the idea that ransom prices have become inflated, making negotiations more difficult).

73. The G8 is an unofficial governmental forum of eight of the world's leading industrialized democracies: Canada, France, Germany, Italy, Japan, Russia, the United Kingdom, and the United States. The group meets annually to discuss and address "major economic and political issues facing member states and the international community." FACTBOX: The Group of Eight: What Is It?, REUTERS (July 3, 2008, 5:49 AM), http://uk.reuters.com/article/2008/07/03/us-g8-group-idUKB26280520080703?sp=true [https://perma.cc/4248-PVPF] [hereinafter The Group of Eight]. In March 2014, Russia was suspended from the G8 because of its actions against in Ukraine. Alison Smale \& Michael D. Shear, Russia is Ousted from Group of 8 by U.S. and Allies, N.Y. TIMES (Mar. 24, 2014), http://www.nytimes.com/2014/03/25/world/europe/obama-russia-crimea.html?r=0.

74. See Steven Swinford, David Cameron Tells G8 Nations to Stop Paying Ransoms to Terrorists, TELEGRAPH (June 6, 2013, 5:31 PM), http://www.telegraph.co.uk/ news/worldnews/g8/10104374/David-Cameron-tells-G8-nations-to-stop-paying-ransomsto-terrorists.html (quoting the Prime Minister as stating that he wanted countries "to sign up to a tangible agreement”).

75. G8 Communiqué, supra note 17, ๆ甲 76-77.

76. Algiers Memorandum, supra note 28, at 2.

77. Algiers Memorandum, supra note 28, at 4. 
The UK followed with a proposal to the United Nations aimed at operationalizing the June 18 Communiqué. ${ }^{78}$ The results of the UK's efforts are memorialized in Security Council Resolution 2133, unanimously adopted in January 2014. ${ }^{79}$ The resolution ostensibly creates "no new legal obligations," but was apparently "designed to increase political pressure on countries not to pay ransoms." Council "reaffirmed" "its resolution 1373 (2001)"81 and in particular its "decision" that all States "prevent and suppress the financing of terrorist acts and refrain from providing any form of support, active or passive, to entities or persons involved in terrorist acts . . .."82 It further "reaffirmed" "its decision in resolution 1373 (2001) that all States shall prohibit their nationals . . . from making any funds, financial assets or economic resources . . . available, directly or indirectly, for the benefit of persons who commit . . . terrorist acts ...."83 As to ransom payments more specifically, the resolution "calls upon" all states "to prevent terrorists from benefiting directly or indirectly from ransom payments or from political concessions and to secure the safe release of hostages." ${ }^{84}$ It further "calls upon" states "to encourage private sector partners to adopt or to follow relevant guidelines and good

78. Adoption of a Resolution on Terrorist Kidnapping for Ransom, WHAT's IN BLUE (Jan. 24, 2014, 5:26 PM), http://www.whatsinblue.org/2014/01/adoption-of-aresolution-on-terrorist-kidnapping-for-ransom.php [https://perma.cc/4TGV-BB3Y].

79. Press Release, U.N. Security Council, Security Council Adopts Resolution 2133 (2014), Calling Upon States to Keep Ransom Payments, Political Concessions From Benefitting Terrorist (Jan. 27, 2014), http://www.un.org/press/en/2014/sc11262.doc.htm.

80. Michelle Nichols, U.N. Security Council Urges End to Ransom Payments to Extremists, REUTERS (Jan. 27, 2014, 5:21 PM), http://www.reuters.com/article/2014/ 01/27/us-kidnappings-ransoms-un-idUSBREA0Q1RI20140127 [https://perma.cc/XJF2-JMHR].

81. S.C Res. 1373 (Sept. 28, 2001). Resolution 1373 was a U.S.-led initiative, and the Security Council passed the resolution unanimously only days after the events of 9/11 as a logical next step in the Council's counterterrorism efforts. Id. Acting under Chapter VII, the Council imposed upon states obligations of a general character, requiring them to act to "prevent and suppress terrorist financing and refrain from providing any other form of support to terrorist groups." Ian Johnstone, Legislation and Adjudication in the UN Security Council: Bringing Down the Deliberative Deficit, 102 AM. J. INT'L L. 275, 284 (2008); see also Andrea Bianchi, Assessing The Effectiveness of the UN Security Council's Anti-Terrorism Measures: The Quest For Legitimacy And Cohesion, 17 EuR. J. INT'L L. 881, 881-83 (2006); id.

82. S.C. Res. 2133, ๆ 1 (Jan. 27, 2014).

83. Id. 12.

84. Id. $\uparrow 3$. 
practices for preventing and responding to terrorist kidnappings without paying ransoms.", 85

Additional resolutions referencing a ban on ransom payments have followed. In both Resolutions $2170(2014)^{86}$ and 2199 (2015), ${ }^{87}$ the Council acted under Chapter VII to confirm - or reaffirm, in the case of Resolution 2199- " "that the requirements in paragraph 1(a) of resolution 2161 (2014)" "apply to the payment of ransoms to individuals, groups, undertakings or entities on the Al-Qaida Sanctions List, regardless of how or by whom the ransom is paid."88 That paragraph of Resolution $2161^{89}$ contains the Council's "decision" acting under Chapter VII that states "shall” freeze "the funds and other financial assets or economic resources" of al Qaeda or individuals or groups associated with them "and ensure that neither these nor any other funds, financial assets or economic resources are made available, directly or indirectly for such persons' benefit, by their nationals or by persons within their territory."90 In Resolution 2199 (2015), the Council further acted under Chapter VII to again "call upon" states "to prevent terrorists from benefiting directly or indirectly from ransom payments or from political concessions and to secure the safe release of hostages." Resolution 2199 also reiterates the Security Council's prior "calls" to "encourage private sector partners to adopt or to follow relevant guidelines and good practices for preventing and responding to terrorist kidnappings without paying ransom.",92

\section{Legally-Binding or Not: A Textual Analysis}

This section analyzes the language of the G8 Communiqué and the various Security Council resolutions to assess the nature of the obligations they place upon states. This Article concludes that referenced measures do not create clear, binding, and enforceable obligations that require states to refuse to pay ransoms to terrorists or otherwise face sanctions or other coercive measures to ensure compliance.

Consider the limitations of the G8 Communiqué. It contains the pledge of only eight states. ${ }^{93}$ Nor is the pledge unambiguous as to the obligations of those eight states. The G8 state that they "unequivocally reject the payment

85. Id. $₫ 10$.

86. S.C. Res. 2170 (Aug. 15, 2014).

87. S.C. Res. 2199 (Feb. 12, 2015).

88. S.C. Res. 2170, ๆ 17 (Aug. 17, 2014); S.C. Res. 2199, ๆ 19 (Feb. 12, 2015).

89. S.C. Res. 2161, ๆ 1(a) (June 17, 2014).

90. Id.

91. S.C. Res. 2199, ๆ 20 (Feb. 12, 2015).

92. Id. $₫ 19$.

93. See supra notes $73-75$ and accompanying text. 
of ransoms to terrorists" and that they "welcome efforts to prevent kidnapping and secure the safe release of hostages without ransom payments." While this language may be interpreted as a ban on ransoms, absent is a simple and clear promise never to pay a ransom to terrorists. Even if the language was specific, the G8 is an informal institution with no law-making or enforcement powers. ${ }^{95}$ Moreover, it has been criticized in the past for failing to live up to its promises. ${ }^{96}$ In short, the G8 Communiqué does not create a binding legal obligation to refrain from acceding to ransom demands that can be enforced against states. ${ }^{97}$

The Security Council is different: it can bind states. Paragraph 1 of Article 24 of the UN Charter provides that the Security Council has the power to act on behalf of member states to maintain international peace and security. ${ }^{98}$ In responding to a threat to international peace and security, the Council has powers under Chapter VII to authorize the use of force. ${ }^{99}$ In addition, it has the power to "decide what measures not involving the use of armed force are to be employed to give effect to its decisions, and it may call upon the Members of the United Nations to apply such measures." 100 On the other hand, under Article 25 of the Charter, member states agree to carry out and accept only the Council's "decisions"-as opposed to, for example, its "recommendations.", States are only required

94. G8 Communiqué, supra note 17 , at 9 १ 76-77.

95. Risto E.J. Penttila, The Role of the G8 in International Peace \&SECURITY 7 (2003); see also Peter Holcombe Henley \& Niels M. Blokker, The Group of 20: A Short Legal Anatomy from the Perspective of International Institutional Law, 14 MELB. J. INT'L L. 550, 559-60 (2013) (stating that the G8 “remains an informal grouping which aims to facilitate coordination, but falls short of requiring its members to commit to legally binding cooperation").

96. Zachary Laub, Backgrounder: The Group of Eight (G8) Industrialized Nations, Council On Foreign Relations (Mar. 3, 2014), http://www.cfr.org/internationalorganizations-and-alliances/group-eight-g8-industrialized-nations/p10647 [https://perma. cc/T58T-XHG7] (noting that the failure of the G8 states to live up to their commitments has been the subject of much criticism and that accountability has accordingly become a larger part of the group's current agenda).

97. Camilla Bausch \& Michael Mehling, Chapter 6 Alternative Venues of Climate Cooperation: An Institutional Perspective, 21 IUS GENTIUM 111, 122 (2013) (stating that the "G8 summits aim primarily to send political signals and set trends, and do not produce binding results").

98. U.N. Charter art. 24, $₫ 1$.

99. U.N. Charter art. 42

100. U.N. Charter art. 41.

101. U.N. Charter art. 25 ("The Members of the United Nations agree to accept and carry out the decisions of the Security Council in accordance with the present Charter.”); 
to comply with Council decisions, and then one must parse the language used in any Council decision in order to determine the precise obligations to which states are bound. ${ }^{102}$

Reviewing the language of the resolutions referenced above reveals that the Security Council has not clearly and unambiguously issued a decision banning states or their citizens from meeting terrorist ransom demands. In Resolution 1373, the Council issued decisions that it later reaffirmed in each of Resolutions 2133 and 2170. ${ }^{103}$ Those Resolution 1373 decisions, however, do not explicitly reference ransom payments. ${ }^{104}$ Instead, the decisions the Council "reaffirmed" are more general in nature. One requires states to prevent and suppress the financing of terrorist acts and refrain from providing any active or passive support to those involved in terrorist acts. ${ }^{105}$ The other requires states to prohibit nationals from making funds available, directly or indirectly, for the benefit of persons - or entities

see also Marko Divac Öberg, The Legal Effects of Resolutions of the UN Security Council and General Assembly in the Jurisprudence of the ICJ, 16 EUR. J. INT'L L. 879, 884 (2006) (noting that Security Council "decisions" are binding on Member States, but that "recommendations" are not); Carsten Stahn, The Ambiguities of Security Council Resolution 1422 (2002), 14 EUR. J. INT'L L. 85, 102 (2003) (noting that Article 25 of the UN Charter only establishes a duty to carry out "decisions" by the Security Council).

102. See Öberg, supra note 101, at 885 (citing to a decision of the International Court of Justice for the proposition that " $[\mathrm{w}]$ hether a specific SC resolution is binding is determined by the language used in it, the discussions leading to it, the Charter provisions invoked, etc.”); Stahn, supra note 101, at 101-02 (interpreting the language of a Security Council resolution in order to reach conclusions about its binding effect).

103. S.C. Res. 2133, ๆף 1-2 (Jan. 27, 2014); S.C. Res. 2170, ๆ 11 (Aug. 15, 2014).

104. Some commentators have argued that the Security Council does not have the mandate to act as a "global legislator" and issue resolutions like Resolution 1373 that purport to impose general and far-reaching obligations on U.N. Member states so as to address threats posed by terrorism. Essentially, the question is whether it is appropriate for this small political body whose decisions are not reviewable to impose far-reaching legal obligations upon states. See Eric Rosand, The Security Council As "Global Legislator": Ultra Vires or Ultra Innovative, 28 FORDHAM INT’L L. J. 542, 543 \& n.5, 552, 573 (2005). Rosand, however, concludes that nothing in the U.N. Charter limits the Council from using its Chapter VII powers in a legislative capacity. See id. at 559; see also Johnstone, supra note 81, at 299 ("While the Security Council is first and foremost an executive body whose principle function is crisis management, no evident legal rule prohibits it from acting in a legislative or quasi-judicial manner.”). This Article does not engage with this debate and instead assumes for its purposes that the Council had the power to issue its decisions in Resolution 1373.

105. See S.C. Res. 2133, I 1 (Jan. 27, 2014); S.C. Res. 2170, 111 (2014); S.C. Res. 1373, ๆף 1(a), 2(a) (Sept. 28, 2001). Resolution 1373, paragraph 1(a) states that the Council "[d] ecides that all States shall [p]revent and suppress the financing of terrorist acts." S.C. Res. 1373, ๆ 1(a) (Sept, 28, 2001). In paragraph 2(a), it “[d] ecides also that all States shall [r]efrain from providing any form of support, active or passive, to entities or persons involved in terrorist acts, including by suppressing recruitment of members of terrorist groups and eliminating the supply of weapons to terrorists.” S.C. Res. 1373, ๆ 2(a) (Sept. 28, 2001). 
owned or controlled by them or of persons or entities acting on their behalf-who commit or attempt to commit, facilitate, or participate in terrorist acts. ${ }^{106}$ One could argue that "ransoms" are necessarily included within the phrases "providing active or passive support" or "making funds available."107 On the other hand, states likely have a good argument that Resolution 1373 did not bind them to a ransom ban given the lack of any explicit reference to ransoms.

Nor do the later resolutions referencing Resolution 1373 unequivocally set out a legally binding obligation to ban terrorist ransom payments. Resolutions 2133 and 2199 explicitly refer to "ransoms," but not in the context of a "decision." In both, the Security Council "notes" "ransom payments to terrorist groups are one of the sources of income that supports their recruitment efforts, strengthens their operational capability to organize and carry out attacks, and incentivizes future incidents of kidnapping from ransoms."108 "Noting," however, is not the same as a "deciding” to ban states from paying ransoms. Nor is it a clarification that ransom payments are included in the broad language of the Resolution 1373 decisions reference above. Resolution 2133 contains a further statement that "calls upon" states "to prevent terrorists from benefiting directly or indirectly from ransom payments." "109 Absent is the word "decides" prefacing this "call." Resolution 2199 is similar: it only "reiterates" the same "call” "to prevent terrorists from benefiting directly or indirectly from ransom payments."110

Resolution 2161 also contains decisions that the Security Council later “confirmed” or "reaffirmed," in Resolutions 2170 and 2199, respectively. ${ }^{111}$ Specifically, both resolutions state that the requirements of the Council's decision in paragraph 1(a) of Resolution 2161 shall also "apply to the

106. See S.C. Res. 2133, ๆ 2 (Jan. 27, 2014); S.C. Res. 1373, ๆ 1(d) (Sept. 28, 2001). Resolution 1373, paragraph 1(d) states that the Council

[d]ecides that all States shall [p]rohibit their nationals or any persons and entities within their territories from making any funds, financial assets or economic resources or financial or other related services available, directly or indirectly, for the benefit of persons who commit or attempt to commit or facilitate or participate in the commission of terrorist acts, of entities owned or controlled, directly or indirectly, by such persons and of persons and entities acting on behalf of or at the direction of such persons.

S.C. Res. 1373, ๆ 1(d) (Sept. 28, 2001).

107. See supra notes 105-06.

108. See S.C. Res. 2133, ๆ 7 (Jan. 27, 2014); S.C. Res. 2199 (Feb. 12, 2015).

109. See S.C. Res. 2133, ๆ 3 (Jan. 27, 2014).

110. S.C. Res. 2199, \ 20 (Feb. 12, 2015).

111. See discussion supra notes 86-90. 
payment of ransoms." ${ }^{112}$ In paragraph 1(a) of Resolution 2161, the Council decided states must freeze the funds or assets of terrorists-no matter from what source those funds or assets were obtained. ${ }^{113}$ Thus, the later resolutions seem to clarify that the requirement to freeze assets also applies to ransom payments. Neither Resolution 2177 nor Resolution 2190 contains language that definitively prohibits states from paying ransoms. Perhaps the language of these resolutions, taken together, means that if states learn of ransom payments, they should freeze them or the assets of one who paid a ransom. Again, if the Council wanted to clearly ban states from paying ransoms, it could have used precise language to do just that.

The fact that states have paid terrorists more than $\$ 100$ million in ransom payments since the Security Council issued Resolution 1373 also supports a conclusion that the measures discussed do not create a legallybinding obligation to ban terrorist ransom payments. Yet while research revealed statements by government representatives and others criticizing these states for paying ransoms, research has not revealed any instance where the Security Council or anyone else went on record saying that the payments were made in violation of Resolution $1373 .{ }^{114}$ If the Security Council believed it had banned states from paying ransoms by some language in Resolution 1373 or any of the later resolutions, should we expect it to stand by silently? It could have issued a statement pointing out that it had issued a binding decision to which states must adhere. It could have referenced an enforcement mechanism that would be employed to hold states accountable to banning terrorist ransoms.

Finally, there is even less reason to believe that the G8 Communiqué or the Security Council resolutions legally bind states to ban their citizens from paying ransoms to terrorists. The G8 have no authority to bind. ${ }^{115}$ In any event, as to individuals, the Communiqué only "encourages” private sector parties to obtain the safe release of hostages without paying ransoms through efforts such as those recommended in the Algiers Memorandum issued by the Global Counterterrorism Task Force. ${ }^{116}$ The Security Council resolutions are similar in that they simply "encourage.” In Resolution 2133, the Security Council "calls upon" states to "encourage" individuals to respond to kidnappings without paying ransoms. ${ }^{117}$ Resolution 2199, issued in

112. S.C. Res. 2170, ๆ 17 (Aug. 15, 2014); S.C. Res. 2199, ๆ 19 (Feb. 12, 2015).

113. S.C. Res. 2161, ๆ 1(a) (June 17, 2014).

114. See, e.g., Tom McTague, European Leaders to Be 'Good to Their Word' and Stop Funding ISIS with Ransom Payments, DaILY MaIL (Sept. 3, 2014, 10:45 AM), http://www.dailymail.co.uk/news/article-2742272/Cameron-tells-European-leaders-goodword-stop-funding-ISIS-ransom-payments.html.

115. Bausch \& Mehling, supra note 97, at 122.

116. G8 Communiqué, supra note 17 , at 977.

117. S.C. Res. 2133, ๆ 10 (Jan. 27, 2014). 
2015, is identically worded. ${ }^{118}$ These "calls" allow the states themselves to decide whether to require their citizens to adhere to a terrorist ransom ban.

\section{MAKING THE CASE FOR THE RECENT MEASURES: NORM INFLUENCE}

If the recent measures are not binding and enforceable, then do they matter at all? After all, at present, they do not serve as a basis to force states or their citizens to refuse to pay ransoms. This Article, however, argues that the recent measures matter, because they have the potential to impact behavior in a meaningful and constructive way in the future. The G8 Communiqué and the various Security Council resolutions mark a significant development: two influential international institutions are now urging states to implement a universal terrorist ransom ban as to themselves and their citizens. The United States and the United Kingdom have been vocal about their no-concessions policies, and they have sought to persuade others of the value of their positions. ${ }^{119}$ But the message of two stateseven powerful states-arguably does not have the same persuasive force as a message backed more multilaterally.

\section{A. Norm Influence and the Terrorist Ransom Ban Measures}

This Article draws on the literature about norm influence to support its argument about the role the G8 Communiqué and the Security Council Resolutions can play in changing state and individual behavior as regards paying ransoms to terrorists. In their influential article addressing the role norms play in political change, Finnemore and Sikkink define a norm as "a standard of appropriate behavior for actors with a given identity." 120 They suggest that we can identify "appropriate" behavior by reference to the judgment of a particular society or community: norm-breaking behavior generates disapproval or stigma, while norm-adhering behavior does not. ${ }^{121}$ On the other hand, what is appropriate can vary not only with societies or

118. S.C. Res. 2199, ๆ 19 (Feb. 12, 2015).

119. See, e.g., Boucher, supra note 9 (describing the U.S. policy not to pay ransoms); Deardon, supra note 9 (referencing the UK's 40-year-old no-concessions policy).

120. Finnemore \& Sikkink, supra note 22, at 891.

121. Id. at 891-92. 
communities, but also over time. ${ }^{122}$ In other words, new norms can emerge and spread. Scholars have suggested a three-stage process: the first stage is norm emergence; the second stage is norm diffusion, where a critical mass of actors agree to abide by the emerging norm; and the last stage is the institutionalization stage, where the new norm is robust enough that actors reflexively conform to it. ${ }^{123}$ Nevertheless, as Finnemore and Sikkink caution, completing this norm "life cycle" is not guaranteed; many emergent norms will not reach a stage of mass diffusion. ${ }^{124}$

The two elements that scholars tend to agree must be present in order for a new norm to emerge and spread are norm entrepreneurs and organizational platforms. ${ }^{125}$ Norm entrepreneurs are agents who use information about the nature of a problem and arguments about the problem's importance in an effort to persuade others of the need for a new norm. ${ }^{126}$ They feel compelled to advocate for a new norm and new standard of conduct when they become dissatisfied with an existing state of affairs. ${ }^{127}$ To persuade other critical actors to change their behavior, "norm entrepreneurs should possess powerful and convincing rhetorical and communicative skills." 128

The organizational platform is critical to the norm entrepreneur's ability to reach the second and third stages in the norm life cycle: diffusion and institutionalization. Organizational platforms come in different forms. They can be international institutions, such as the United Nations. They can also be non-governmental organizations. ${ }^{129}$ In all cases, though, the platform must be one that provides the entrepreneur with access to critical audiences that can help to promote the norm. ${ }^{130}$ That organizational platform also should give the norm entrepreneur access to the organization's expertise

122. The word "appropriately" references the "logic of appropriateness," whereby actors are driven by what is right, as opposed to what might be demanded of them or legally required. See James G. March \& Johan P. Olsen, The Logic of Appropriateness, in The OXFord HandBook Of Public Policy 689-90 (Michael Moran et al. eds., 2008).

123. Finnemore \& Sikkink, supra note 22, at 895, 898; Knight, supra note 23, at 18.

124. Finnemore \& Sikkink, supra note 22, at 895.

125. Id. at 896; Darren Hawkins \& Joshua Lloyd, Questioning Comprehensive Sanctions: The Birth of a Norm, 2 J. HuM. RTs. 441, 442 (2003).

126. Hawkins \& Lloyd, supra note 125, at 442.

127. Knight, supra note 23, at 18.

128. Id. See also Finnemore \& Sikkink, supra note 22, at 897 ("The construction of cognitive frames is an essential component of norm entrepreneurs' political strategies, since, when they are successful, the new frames resonate with broader public understandings and are adopted as new ways of talking about and understanding issues.”).

129. Finnemore \& Sikkink, supra note 22, at 900.

130. See, e.g., Finnemore \& Sikkink, supra note 22, at 900 (suggesting that the organizational platform should allow access to an audience); Hawkins \& Lloyd, supra note 125, at 442 (suggesting that organizational platforms should enable the norm entrepreneur to distribute information). 
and information so as help influence behavior-to make norm breakers into norm followers. ${ }^{131}$ In the international context, norm entrepreneurs and their networks will use both praise of conforming behavior and ridicule of non-conforming behavior to socialize other relevant actors and persuade them to adopt the new policy. ${ }^{132}$

Consider the G8 Communiqué and the Security Council resolutions in this context. Prime Minister Cameron has acted as a norm entrepreneur. He has persuaded the G8 members and the Security Council to push through measures referencing a more universal preference for refusing to pay ransoms to terrorists. These measures have altered the previous landscape, one where two states essentially stood alone in their resolve to follow a strict no-concessions policy despite the costs in terms of lives lost in the short term. The G8 states publicly pledged that they would not pay ransoms. The Security Council Resolutions contain relatively strong wording in that they "urge" states to refuse to pay ransoms. Though neither measure is legally binding, each is a step in the road towards adopting a more universal norm of rejecting ransoms to terrorists.

Furthermore, there are now two organizational platforms promoting the new norm that norm entrepreneurs can leverage to pursue further efforts to persuade states to commit to a ransom ban, not only in theory, but also in practice. Indeed, Prime Minister Cameron has leveraged the G8 platform to help socialize relevant actors to the new norm by bringing attention to non-conforming behavior. In September 2014, the prime minister called out France and Germany for paying ransoms to ISIS and implored them to be "good to their word" - the pledge they made as part of the G8 Communiqué. ${ }^{133}$

None of this means that the norm of banning ransoms to terrorists will be quickly adopted or institutionalized by a greater number of states. This stage of norm emergence may never materialize into something greater. On the other hand, there is now a foundation for interested stakeholders to push forward an agenda of persuading states of the value of changing their behavior. And at least one study indicates that this very type of nonbinding "urging" by the Security Council has served to promote normative change over time. Professor of Law Cora True-Frost found that the adoption of some non-binding Security Council resolutions addressing non-situation-

131. See Finnemore \& Sikkink, supra note 22, at 899, 902.

132. Id. at 902.

133. McTague, supra note 114. 
specific human security concerns helped bring about actual changes in behavior. ${ }^{134}$

For example, in one case study, True-Frost examined the effects of Security Council Resolution 1325 "calling upon” and "urging” states to increase women's participation in U.N. conflict and peacekeeping operations. ${ }^{135}$ A transnational advocacy network of women's organizations had successfully lobbied the Council to adopt this resolution in 2000. ${ }^{136}$ Among other developments, True-Frost found that Resolution 1325 prompted "roundtables, trainings and gender awareness sessions for Security Council members, UN agencies, and grassroots activists."137 "Members of civil society have also leveraged Resolution 1325 to support their advocacy and to secure funding for women's programs." ${ }^{\text {"138 }}$ On the national level, among other things, True-Frost found evidence that some states had developed action plans to implement Resolution $1325 .{ }^{139}$ However, a word of caution is in order: True-Frost did not find that the Resolution quickly resulted in some ideal outcome with women equally participating in peacekeeping and conflict matters. ${ }^{140}$ Nevertheless, positive change did occur despite the absence of coercive legally binding pronouncements.

\section{B. Considering the Alternative: Force Instead of Persuasion}

This Article argues that the only realistic avenue to produce any significant behavioral change in this context is through persuasion, as opposed to force. As an initial matter, there is little reason to expect that the relevant states would have backed a G8 communiqué or a Security Council resolution that clearly banned them or their citizens from paying terrorist ransoms. The G8 issues communiqués only when its member states agree. In the case of the Security Council, any of the five permanent members (P5) ${ }^{141}$ can veto any substantive action of the Council, including resolutions issued

134. C. Cora True-Frost, The Security Council and Norm Consumption, 40 INT'L L. \& PoL. 115, 121 (2007) (stating that the resolutions in some cases brought about "the prescribed normative behavior" and in other cases, "undeniably provided a discursive framework for the development and implementation of the relevant norms").

135. See id. at 146-47 (describing in detail the provisions contained in Resolution 1325).

136. Id. at 154.

137. Id. at 160 .

138. Id. at 162 .

139. Id. at 164-65.

140. See, e.g., id. at 167-68.

141. The P5 includes China, France, Russia, the United Kingdom, and the United States. See Current Members, U.N. SEC. CounCIL, http://www.un.org/en/sc/members/ [https://perma.cc/2M3P-BVGS] (last visited June 12, 2016). 
to carry out its powers under Chapter VII. ${ }^{142}$ Research has not revealed any evidence-like contemporaneous statements from European leadersshowing that they support a binding ban backed by enforcement mechanisms so as to tie their hands to commit them to new behavior. In fact, France is a member of both the G8 and P5, and states have accused it of paying ransoms even after the passage of the G8 Communiqué. ${ }^{143}$

The likely absence of broad state support for a legally binding ransom ban is not the only reason why proceeding by way of persuasion, instead of force, makes sense. Persuasion avoids a host of practical and ethical concerns associated with trying to force states and their citizens to adhere to a strict policy of not paying ransoms to terrorists. Below, this Article addresses such concerns relating to the enforcement of a hypothetical legally binding terrorist ransom ban directed at (1) state governments and (2) individuals.

\section{Obstacles to a Legally-Binding Terrorist Ransom Ban Directed at Governments}

The obstacles to a legally-binding terrorist ransom ban directed at governments are both practical and ethical. As a practical matter, there is the ease with which states can evade such a ban and the corresponding difficulty of obtaining evidence of such evasion. States have paid ransoms in the past, and they will likely be unable to resist the temptation to continue to pay unless they become convinced that the only right course of action is to refuse to pay ransoms in order to save future lives. If instead they believe that the only right and ethical behavior is saving the life of an innocent hostage, a ban will serve as little deterrent. And when states do pay ransoms, they do not do so openly; they often deliver cash in suitcases. ${ }^{144}$ Tracking cash moved in suitcases, rather than through banking channels, is not an easy matter. Such tactics allow those who pay to avoid leaving

142. See U.N. Charter art. 27 (stating that substantive decisions of the Security Council require the affirmative vote of seven members, including the concurring votes of the permanent members); see also Asad Hashim, Veto Power at the UN Security Council, AlJAZEERA (Feb. 5, 2012), http://www.aljazeera.com/indepth/features/2012/02/2012251 52330761377.html [https://perma.cc/Y2Y4-NTPV] (reporting that only the permanent five members of the Security Council have the power to veto the Council's resolutions).

143. See, e.g., McTague, supra note 114 (calling out France, among other states, for paying ransoms to ISIS); Millions Paid, supra note 56 (reporting that France paid ransoms to AQIM for the release of French citizens).

144. See, e.g., supra note 2. 
an evidentiary trail. ${ }^{145}$ The Security Council may not be able to createor willing to devote the resources necessary to create-a monitoring mechanism strict enough to enable it to find credible evidence of a government's ransom payment.

The Financial Action Task Force’s February 2015 Report addressing ISIL's financing explains the difficulty of tracking ransom payments generally. It states:

Exact figures with respect to how much ISIL has earned from ransom payments are difficult to assess and often intentionally kept secret since ransom payments often originate from private companies that wish to conceal the transaction, or are otherwise paid in cash, making the transactions difficult for financial institutions to identify. 146

If the FATF has difficulty tracking individual payments, imagine the difficulty of tracking the payments of a sovereign state. Some people in government may be willing to tell a reporter that their government paid, but this does not mean that the government will permit the Security Council or other states to review its financial records. Even if governments did agree to such a review procedure, they could hide the payment under any line item not entitled "ransom payment."

Indeed, enforcement is always more difficult in the international arena than in the domestic. National prosecutors have many tools at their disposal to aid them in bringing those who commit crimes to justice. They can subpoena documents and witnesses. They can apply for search warrants. Also, when national prosecutors obtain an arrest warrant, they can have that warrant executed by a police force. In the international context, states cannot generally force other states to turn over evidence implicating their leadership in bad or criminal behavior. Nor is there an international police force to arrest offenders. The international arena, instead, depends on state cooperation.

There are also reasons to believe that neither the Security Council nor individual states would want to bear the ethical burden of forcing another state to refuse to accede to terrorist ransom demands. The usual result of the refusal to pay is that the state's citizen suffers a gruesome and often widely publicized death. Urging states and citizens to refuse to pay ransoms because doing so serves the greater goals of depriving terrorists of funding and the motivation for future kidnappings is different from forcing one not to pay a ransom. When one "urges," as opposed to "forces," one does not assume the ultimate decision of whether to pay or not. By allowing

145. FIN. ACTION TASK FORCE, FINANCING OF THE TERRORIST ORGANIZATION ISLAMIC STATE IN IRAQ AND THE LEVANT (ISIL) 18 (2015).

146. Id. 
the state to decide on its own to follow a no-concessions policy, the Security Council and states may then feel that they can absolve themselves of the ethical responsibility for the death of another state's citizens.

\section{Obstacles to a Legally Binding Terrorist Ransom Ban Directed at Individuals}

There are also obstacles to adopting a legally binding terrorist ransom ban directed at individuals. One practical problem relates to enforcing any ban on terrorist ransoms directed at individuals. In the domestic context, as noted, states do have resources to gather evidence of criminal behavior and arrest offenders. However, laws are also supposed to deter individuals from committing crimes because individuals would rather not be punished. ${ }^{147}$ One can imagine that the threat of imprisonment would not deter a great number of parents from paying a ransom if doing so meant that their child might not be murdered by terrorists. In fact, some parents of hostages have said as much in response to threats that they "risked prosecution if they paid terrorists or tried to persuade an allied power to do so."148 The father of Jim Foley stated that he would rather be in prison if he could have his son home. ${ }^{149}$ The mother of another hostage said, "Let them put me in jail." 150

Force and threats likely will not induce parents to refuse to accede to ransom demands when the alternative is the possibility that their child will die at the hands of terrorists. Persuasion, though, might prove to be an effective tactic. Why? If parents are convinced that paying terrorists is the wrong thing to do because it fuels further terrorist acts and puts others at risk of being held hostage in the future, then maybe parents themselves will choose not to pay. Here, too, the comments of the parents of some individuals recently being held hostage by terrorists are helpful. One set of parents reported staying "up late worrying about the morality of giving money to a terrorist group-yet their only child's life was at stake, and

147. See, e.g., Raymond Pasternoster, How Much Do We Really Know About Criminal Deterrence?, 100 J. CRIM. L. \& CRIMINOLOGY 765, 766 (2010) ("The concept of deterrence is quite simple-it is the omission of a criminal act because of the fear of sanctions or punishment.").

148. Lawrence Wright, Five Hostages, NEw YORKER (July 6, 2015), http://www.new yorker.com/magazine/2015/07/06/five-hostages [https://perma.cc/R8FC-W9YP].

149. Id.

150. Id. 
ISIS was already rich.”151 The mother of hostage Kayla Mueller said that she did not want ISIS to receive another cent and that she did not think her daughter would want them to either. ${ }^{152}$

However, even if threats to prosecute could deter family members from seeking to pay a ransom, there are moral and ethical reasons why a state should not criminally sanction individuals who succumb to ransom demands. In fact, punishing those who pay under duress would not be consistent with the retributive principles of the criminal law. Ordinarily, the criminal law punishes those who deserve it. ${ }^{153}$ Individuals who pay ransoms to kidnappers pay under duress - in response to a threat to kill the hostage, and not with the intention to further criminal activity. ${ }^{154}$ When someone acts under duress, they act because of fear or coercion. They do something in response to a threat by another to make her worse off than she would have been otherwise. ${ }^{155}$ Although the ransom payment may necessarily assist the kidnapper, the payer does not make the payment with the criminal intent to assist in unlawful activities. Nor does the payer share any illegal profits with the kidnappers. In short, the one who pays a ransom to a kidnapper is a victim. Not unlike the victim of a robbery who gives up a wallet to avoid being harmed, she gives up money in order to avoid the execution of an innocent hostage. ${ }^{156}$

Nor may states be prepared to treat individuals who pay ransoms to terrorists differently than they treat individuals who pay ransoms to "ordinary" criminals. ${ }^{157}$ In fact, the United States has never brought a case against

151. Id.

152. Id.

153. See Michael S. Moore, Placing Blame: A Theory of the Criminal Law 91 (2010) (explaining that retribution is a theory that justifies punishment "because and only because offenders deserve it”).

154. See Joshua Dressler, Exegesis of the Law of Duress: Justifying the Excuse and Searching for its Proper Limits, 62 S. CAL. L. REV. 1331, 1341 (1989). Generally, for the duress defense to be available, the threat must come from a person and be an unlawful threat to imminently cause death or great bodily harm to a human being. Id. at 1339 .

155. Although this Article specifically discusses the law of the United States, it bears noting that other countries following the common law or civil law traditions generally require "criminal intent" and the absence of defenses like "duress" in order to criminally punish. See, e.g., Marcus Dirk Dubber, Comparative Criminal Law, in The OxforD HANDBOOK OF COMPARATIVE LAw 1319 (2012) (describing German criminal law as requiring criminal intent, as well as the absence of justification or excuse defenses).

156. See, e.g., GEORGETOWN UNIVERSITY LAW CENTER, HUMAN Rights INSTITUTE, UNINTENDED CONSEQUENCES: REFUGEE VICTIMS OF THE WAR ON TERROR 23 n.157 (Mark Fleming et al. eds., 2006) ("In the criminal context, an individual forced to give money or goods to an armed group would be considered a victim of criminal extortion, not a participant in the crime under U.S. criminal law.”).

157. Necessity is a defense to criminal liability similar to duress in that it justifies or excuses the actor's otherwise criminal behavior. In the United States, however, the necessity defense is typically available only in response to natural forces: for example, when one 
any of its citizens arguing that by paying a ransom, they have violated the law prohibiting providing "material support" to a terrorist organization. ${ }^{158}$ Yet the United States adheres to a strict no-concessions policy and urges its citizens to also not accede to ransom demands. Also, the language of the "material support" provision in 18 U.S.C. § 2339B is arguably broad enough to include ransom payments. ${ }^{159}$ That law criminalizes the conduct of knowingly providing "material support" to a foreign terrorist organization (FTO) or attempting or conspiring to do the same. 160 "Material support" includes providing currency, monetary instruments, or financial securities. ${ }^{161}$

Based on the language of Section 2339B and the Supreme Court's decision in Holder v. Humanitarian Law Project, one can be criminally liable for financing terrorism if the prosecution shows that the person providing support knew that she was giving money to a designated FTOwithout also showing the person intended to further unlawful activities. ${ }^{162}$ In Humanitarian Law Project, some individuals and organizations challenged the constitutionality of section 2339B's “material support”

commits a crime that would constitute the lesser of two evils in response to a naturally caused condition, such as a hurricane. See Dressler, supra note 154, at 1347-48. This Article confines its discussion of United States law to the duress defense.

158. See Press Release, The White House, Statement by the President on the U.S. Gov't's Hostage Policy Review (June 24, 2015), [hereinafter White House Press Release] https://www.whitehouse.gov/the-press-office/2015/06/24/statement-president-us-governmentshostage-policy-review [https://perma.cc/BLG4-ADDS] (pointing out "that no family of an American hostage has ever been prosecuted for paying a ransom for the return of their loved ones”).

159. The "material support" provisions are contained in the Antiterrorism and Effective Death Penalty Act of 1996 (AEDPA). Pub. L. No. 104-132, 110 Stat. 1214 (1996) (codified at scattered sections of 28, 21 and 18 U.S.C.). One provision, section 2339A, makes it a federal crime to provide "material support" knowing or intending that such support is to be used in preparation for, or to carry out, specified crimes of terrorism. 18 U.S.C. § 2339A (2012). Section 2339B criminalizes the broader conduct of knowingly providing "material support" to a foreign terrorist organization (FTO), or attempting or conspiring to do the same. 18 U.S.C. $\S 2339 B$ (2012).

160. 18 U.S.C. $\S 2339 B$ (emphasis added). FTOs are foreign organizations that engage in terrorist activities or terrorism that threatens the security interests of the United States and that the Secretary of States has designated as such according to procedures set forth in section 219 of the Immigration and Nationality Act. An up-to-date list of those who have been designated as FTOs is available on the U.S. State Department's website. Foreign Terrorist Organizations, U.S. DEP'T OF STATE http://www.state.gov/j/ct/rls/other/des/ 123085.htm [https://perma.cc/WF2A-TNSX] (last visited June 12, 2016).

161. 18 U.S.C. § 2339A(b)(1); see also 18 U.S.C. § 2339B(g)(4) (referencing the definition of "material support" in section 2339A).

162. Holder v. Humanitarian Law Project, 561 U.S. 1 (2010). 
provision, arguing among other things that the provision violated their First Amendment right of freedom of speech and association because it failed to require the government to prove that they had a specific intent to further the unlawful ends of the designated FTOs. Instead, they stated that they only wanted to provide training and assistance to support the lawful and nonviolent activities of two groups that were on the FTO list-groups that, although they had committed some terrorist attacks, also worked towards establishing independent states for the Kurds in Turkey and the Tamils in Sri Lanka. ${ }^{163}$ However, the Supreme Court concluded that the statute was constitutional "as to the particular activities plaintiffs [say] they wish to pursue.”164

Although it declined to "address the resolution of more difficult cases that may arise under the statute," the Humanitarian Law Project court did explain why the statute could properly subject to criminal liability even those persons who did not intend to further unlawful activities of those designated as FTOs. ${ }^{165}$ First, the Court noted that by the language of the statute, "Congress plainly spoke to the necessary mental state for a violation of § 2339B, and it chose knowledge about the organization's connection to terrorism, not specific intent to further the organization's terrorist activities.”166 It further noted that a review of the statute's legislative history showed that both Congress and the Executive Branch had determined that "providing material support to a designated foreign terrorist organizationeven seemingly benign support-bolsters the terrorist activities of that organization."167 The Court echoed that determination when it stated:

\footnotetext{
Material support meant to "promot[e] peaceable, lawful, conduct” . . can further terrorism by foreign groups in multiple ways. "Material support" is a valuable resource by definition. Such support frees up other resources within the organization that may be put to violent ends. It also importantly helps lend legitimacy to foreign terrorist groups-legitimacy that makes it easier for those groups to persist, to recruit members, and to raise funds — all of which facilitate more terrorist attacks. 168
}

The absence of a "material support" criminal case based on a ransom payment could mean that no citizen has ever acceded to a terrorist ransom demand, or that the United States government does not have sufficient evidence to prove such a payment beyond a reasonable doubt. However, this Article suggests that the absence of such charges has more to do with the ethical dilemma associated with bringing criminal charges against one

163. Id. at $7-11$.

164. Id. at 8 .

165. Id.

166. Id. at $16-17$.

167. Id. at 36.

168. Id. at 30 . 
who pays under duress to save the life of an innocent victim. The circumstances regarding the Foley case are illustrative. As noted, some government representatives allegedly threatened to bring criminal charges against the parents if they paid a ransom. ${ }^{169}$ But when the press reported the alleged threats, the government denied making them. In fact, Secretary of State Kerry responded to the allegations regarding the threat of prosecution by saying that he was unaware of such threats and would not condone anyone making such statements. ${ }^{170}$ The matter seems settledat least for now. In June 2015, President Obama publicly promised that the United States would not use the "material support" law to punish the families of hostages who accede to ransom demands. The reasons he gave for his promise have an ethical ring to them. The president said "the last thing we should ever do is add to a family's pain with threats [to prosecute]."17

Finally, consider the ethical dilemma associated with criminalizing terrorist ransom payments from the perspective of a prosecutor and jurynamely, putting in place a system that "forces" a ransom ban. Even prosecutors who are firmly convinced that ransom payments fund and fuel terrorism and put future lives at risk may not feel they are doing the right thing in bringing a case against someone who paid a ransom to save a family member, friend, or colleague from being executed by terrorists. And prosecutors have some control over what cases they choose to bring. Nor are juries likely to believe that convicting someone in these circumstances is the right thing to do. Should the duress defense be unavailable, the jury will still learn about the circumstances surrounding the ransom payment and know that the defendant paid in response to a threat to kill. Under such circumstances, can we imagine a jury reaching a unanimous verdict of guilty? Jury nullification is a reality. ${ }^{172}$

169. See Ross et al., supra note 64 (referencing the Foley's statement that they had been threatened with prosecution by government representatives); David Rohde, Will Obama's New Hostage Policy Actually Work?, ATLANTIC (June 29, 2015) (stating that senior officials in the White House and State Department repeatedly warned families of hostages that they could be prosecuted if they acceded to the terrorists' ransom demands).

170. $\quad$ Ross et al., supra note 64.

171. See White House Press Release, supra note 158.

172. Jury nullification is the jury's refusal to follow the law as charged by the judge, for example, because they believe the law is unfair or they do not like how it is being applied to a particular defendant. Joan Biskupic, In Jury Rooms, Form of Civil Protest Grows, WASH. POST, Feb. 8, 1999, at A1. 


\section{THE WAY FORWARD: MORE PERSUASION}

States are right to want to do something about the problem posed by terrorist groups' increased use of kidnapping for ransom as a method of financing their illegal organizations. Implementing a no-concessions policy is one way to address the problem. Moreover, states that favor such a policy make persuasive arguments about the potentially positive effects of their stance: they argue that when terrorists learn that kidnapping will not pay, they will be deterred from using KFR as a fundraising tactic. As Under Secretary for Terrorism and Financial Intelligence, David Cohen, puts it: "[r]efusing to pay ransoms or to accede to other terrorist demands is the surest way to convince potential hostage-takers that they will not be rewarded for their crime.”173

This Article argues that the G8 Communiqué and the various Security Council resolutions represent a significant step towards adopting a more universal norm of banning both states and individuals from paying ransoms to terrorists. Even though these measures are not legally binding, they offer a platform from which norm entrepreneurs can use diplomacy to change behavior over the long term. Key to such future change, however, is continued diplomacy so as to persuade states and individuals that not paying ransoms is the appropriate or right thing to do.

What can the norm entrepreneurs do? Leaders in Britain and the United States can seek out other partners in their quest for a ransom ban. They can organize roundtables with state leaders and relevant government and non-governmental organizations. During these roundtables, participants can share information about terrorist organizations, hostage taking, and how terrorist organizations use KFR to fund their illegal activities. Roundtables or similar organized meetings would also provide an opportunity to those who are inclined to pay ransoms to share their concerns with a ransom ban. If the proponents of a ban better understand the objections to a ban, then they can address those objections with arguments and evidence.

Leaders in Britain and the United States can also attempt to persuade in more one-on-one settings. Leaders can make it a priority when meeting with their counterparts in other states to discuss the problem of ransom payments and the reasons why not paying is ethically justified. These leaders must convince those who have previously paid ransoms that giving money to terrorists - even under duress - is wrong because it fuels their illegal operations. They must also convince those who have previously paid that not paying saves more lives in the future because it sends a message that kidnapping will not pay. One way to make these messages more persuasive is to back them up with additional data. States behind a

173. Cohen Statement, supra note 10. 
ransom ban should arm themselves with current data about the amount of money terrorists receive from ransoms, as well as current data on the amount of money terrorists need in order to stage attacks. States supporting a ransom ban would also have a better chance of convincing others to stop paying if they could produce evidence-even anecdotal evidence-to support arguments that cutting off ransom funds would convince terrorists to seek other ways to obtain funding.

To pay or not to pay a ransom to a terrorist poses an ethical dilemma. One should not underestimate the amount of dialogue and persuasive argument that will be required to convince states and individuals that refusing to succumb to a ransom demand is the right thing to do. After all, the evidence suggests that refusing to pay results in the death of an innocent person. 
